\title{
IMPORTANCE OF ISLAMIC FINANCIAL SERVICES ACT 2013 IN TAKAFUL INDUSTRY AFTER THE REPELLED TAKAFUL ACT 1984
}

\author{
Siti Norshila Jamil \& Jasri Jamal *) \\ Faculty of Law, National University of Malaysia, Malaysia \\ jasri@ukm.edu.my
}

\begin{abstract}
The new Malaysian Islamic Financial Services Act 2013 (Act 759) ('IFSA 2013') came into force on the $30^{\text {th }}$ June 2013. Its main objectives are to promote financial stability and compliance to Shariah and further strengthen the regulation of Islamic financial institutions. By this, the IFSA 2013 aims to strengthen consumer protection and further increase the confidence of the public in Takaful. At the same time, it remains to be seen if the IFSA 2013 will also encourage Takaful Operators to take their social and religious responsibility more into consideration, which is fundamental behind the concept of Takaful.
\end{abstract}

Keywords: Takaful, Islamic Financial Services Act 2013

\section{Introduction}

The Financial Services Act (Act 758) and the IFSA 2013 were published in the Government Gazette on the $22^{\text {nd }}$ of March 2013. The new laws came into effect on the $1^{\text {st }}$ of July 2013. The formulation of the new Acts involved the consolidation and rationalization of the Banking and Financial Institutions Act 1989 (Act 372), Insurance Act 1996 (Act 553), Payment Systems Act 2003 (Act 627), Exchange Control Act 1953 (Act 17), Islamic Banking Act 1983 (Act 276) and the Takaful Act 1984 (Act 312) ('TA 1984'). With the new IFSA 2013, it repeals the Islamic Banking Act 1983 (Act 276) and the TA 1984.

The IFSA 2013 is also an omnibus legislation for the regulation and supervision of key Islamic financial institutions such as banks, takaful operators, international Islamic banks, and operators of payment systems using Islamic payment instruments, issuers of Islamic payment instruments, takaful brokers and 
Islamic financial advisor. It also provides for regulation and supervision of payment systems and the oversight of the Islamic money market and Islamic foreign exchange market. The industry players generally support the introduction of IFSA 2013 as it would help create greater transparency, governance and accountability. $^{23}$

\section{Research Methods}

Paper was compiled from the results of the study, using a combination of methods doctrinal and non-doctrinal. The main approaches used include: historical; philosophical approach; comparative; as well as analytical and critical approach. The use of the method based on objective research to see differences in the implementation of insurance services, following the change in the law.

\section{Result and Discussion}

\subsection{The Importance Of Ifsa 2013 In Takaful Industry After The Repelled Ta} 1984

\subsubsection{Exhaustive Definition of Takaful}

The previous TA 1984 defined takaful was statutorily defined as a scheme based on brotherhood, solidarity and mutual assistance which provides for mutual financial aid and assistance to the participants in case of need whereby the participants mutually agree to contribute for that purpose. ${ }^{24}$

Nevertheless, the IFSA 2013 defines takaful as an arrangement based on mutual assistance under which takaful participants agree to contribute to a common fund providing for mutual financial benefits payable to the takaful participants or their beneficiaries on the occurrence of pre-agreed events. ${ }^{25}$

23 Kulsanofer Syed Thajudeen (2014). IFSA 2013: Rational, Salient Features and Possible Issues. The Global University in Islamic Finance: Kuala Lumpur.

24 Section 2 of the Takaful Act 1984 (Act 312).

25 Section 3 of the IFSA 2013 (Act 759). 


\subsubsection{Inclusion of Participants Risk Fund}

The TA 1984 defines takaful as a scheme aims to provide for mutual financial aid to the participants and the participants agree to contribute for such purpose. ${ }^{26}$ However, the definition is silent on the existence of the fund of which the purpose is to maintain all contributions donated by the participants. In comparison to the IFSA 2013, it has included the definition of common fund i.e. tabarru fund or participants risk fund. ${ }^{27}$ Thus, IFSA 2013 has filled the gap of TA 1984.

\subsubsection{Inclusion of the Beneficiaries}

The TA 1984 seems to confine the recipient of takaful benefits to the participants only. If the participant dies, then he or she will not receive the takaful benefits but his or her beneficiaries will receive it. The TA 1984 also loosely describes the payment of mutual financial aid to the participants 'in case of need' but what is the 'case of need' is not specifically defined.

The IFSA 2013 has overcame the situation by including 'the beneficiaries' of the takaful participants as the recipient of the takaful benefits upon the occurrence of the pre-agreed events. ${ }^{28}$ The IFSA 2013 definition of takaful tightens this description by stating that the "case of need" refers to the pre-agreed events as mutually agreed in the takaful certificates.

\subsubsection{Single Licensed Takaful business}

The IFSA 2013 requires a takaful operator with a composite license to separate its Family Takaful business from its General Takaful business. However, the TA 1984 allowed takaful operators to carry on both businesses under the same company. The affected takaful operators are given a grace period of five years from

\footnotetext{
Section 2 of the Takaful Act 1984 (Act 312).

Section 90 of the IFSA 2013 (Act 759).

28 The pre-agreed events would cover death and total and permanent disability ('TPD') of the participant, or any other events as agreed mutually by takaful operator and takaful participants.
} 
the appointed date ${ }^{29}$ to comply with the requirement of Section 16(1) of the IFSA 2013. Any takaful operator who contravenes Section 16(1) of the IFSA 2013 commits an offence and shall, on conviction, be liable to imprisonment for a term not exceeding eight years or to a fine not exceeding RM25 million, or both. ${ }^{30}$

From this situation, the intention of the regulator is to expand the growth of General Takaful business and Family Takaful business. Further the regulator intends the takaful operator to compete with the conventional Insurance practices.

\subsubsection{Minimum Capital Requirements}

Previously, a minimum capital requirement of RM100 million was required to set up a takaful business. The minimum capital requirement for takaful operators is no longer explicitly defined in the IFSA 2013. Instead, the IFSA 2013 states that the minimum capital requirement will be specified by the regulators. ${ }^{31}$

Although the actual impact of this subtle change is currently unknown, this principle-based regulation in the IFSA 2013 may give some scope for regulators to issue capital requirements depending on the nature and complexity of the business. $^{32}$

\subsubsection{To Set Up a Financial Holding Company}

The IFSA 2013 requires takaful operators to set up a Financial Holding Company which will be subject to the requirements under IFSA 2013. Subsequently any takaful operator in Malaysia that is a subsidiary of the Financial Holding Company will be subject to the capital requirements in Malaysia. By being a public company, takaful operators will become a wholly commercial venture.

29 The Appointed Date of the IFSA is 30 June 2013. Accordingly, takaful operator shall have until 30 June 2018 to convert the dual business of family takaful and general takaful to a single takaful business

30 Section 16(2) of the IFSA 2013 (Act 759).

31 Section 12 (1) of the IFSA 2013 (act 759).

32 Zainal Abidin Mohd Kassim and Farzana Ismail (2014). Updates on Takaful:Regulating the Way Forward. 


\subsection{Shariah Governance}

The IFSA 2013 outlines thorough statutory duties for the Board of Directors, Shariah Committee and the management of takaful operators to ensure that the takaful industry achieves Shariah compliant status. The IFSA 2013 upholds the Shariah Governance Framework ('SGF') for Islamic Financial Institutions ('IFIs') issued by Bank Negara Malaysia ('BNM') in 2011. The SGF and other guidelines issued by BNM are given a statutory force by virtue of Section 29 of the IFSA 2013.

Section 29(2) of the IFSA 2013 provides that SGF now becomes a standard that shall be complied with by all IFIs. The ultimate objective of the SGF is to ensure all operations and business activities of IFIs are in accordance with the Shariah. The SGF puts a significant emphasis for the IFIs to establish Shariah compliance functions consisting of Shariah review, Shariah audit, Shariah risk management and Shariah research functions.

Section 29(5) of the IFSA 2013 further puts a personal duty to every director, officer or a member of a Shariah Committee of an institution to ensure that such institution shall at all times comply with the internal policies and procedures adopted by such institution to implement the standards specified by BNM under Section 29(1) and (2). Failure of the IFIs to adhere with the requirements of the SGF will expose the IFIs and its officers to severe statutory punishments as provided under the IFSA 2013.

\subsubsection{Increase Burden on Board of Directors}

The Board of Directors of a licensed Takaful Operator shall give priority to the interest of the Takaful Participants in the event of conflict between the interest of Takaful Participants and Shareholders. ${ }^{33}$ According to Section 66(1) of the IFSA

\footnotetext{
33 Section 65(3)(b) of the IFSA 2013 (Act 759).
} 
2013 any director of a Takaful Operator shall only exercise powers conferred on him according to the IFSA 2013.

Failure to do so will make the Directors liable to imprisonment for a term not exceeding eight years or to a fine not exceeding RM25 million or to both as stated in Section 66(3) of the IFSA $2013 .^{34}$

\subsubsection{Permissible Takaful Interest}

The Shariah Advisory Council ('SAC') of BNM has resolved that the concept of insurable interest does not contradict the Shariah and it may be applied in takaful. $^{35}$

The IFSA 2013 in para 3, Schedule 8 of the IFSA 2013 has imposed the requirement of permissible takaful interest. Paragraph 3(1), Schedule 8 of the IFSA 2013 provides that para 3 is applicable to a family takaful certificate issued in respect of a contract of family takaful entered into by a takaful participant on a person covered other than the takaful participant himself. If a takaful participant entering into such contract of family takaful does not have a permissible takaful interest in the person covered at the time such contract is entered into, the contract shall be void. ${ }^{36}$

Paragraph 3(6), Schedule 8 of the IFSA 2013 explains that a person shall be deemed to have a permissible takaful interest in the person covered if that other person is:

(a) his spouse or child;

(b) his ward under the age of majority at the time the person entered into the contract of takaful;

(c) his employee; or

(d) a person on whom he is wholly or partly, dependent for maintenance or education at the time he entered into the contract of takaful.

Section 66(3) of the IFSA 2013 (Act 759).

35 Shariah Resolutions in Islamic Finance, (2nd Ed), Kuala Lumpur, Bank Negara Malaysia, 2010, p 91.

36 Paragraph 3(3) Schedule 8 of the IFSA 2013 (Act 759). 
Those people listed above are considered to have a clear relationship that involves element of affection, emotional interdependence and reasonable expectation of loss in terms of material or psychological aspects and thus having an insurable interest in the takaful participants or the person covered.

However, such requirement of permissible takaful interest was not specified in the TA 1984. Further to note that Schedule 8 of the IFSA 2013 only provides for permissible takaful interest in family takaful business whereas the IFSA 2013 is silent on the application of permissible takaful interest in general takaful business.

\subsection{Proper Claimant}

Section 65(1) of the TA 1984 only mentioned that payment of takaful benefits may be made to a 'proper claimant'. A proper claimant is a person who claims to be entitled to the takaful benefits as executor of the deceased, or who claims to be entitled to such benefits under the relevant law. ${ }^{37}$

The similar definition of proper claimant is available under the new IFSA 2013. The duty of an executor is namely to distribute the takaful benefits according to the inheritance laws applicable to the takaful participant. With regard to other categories of proper claimant, the new definition of proper claimant under the IFSA 2013 has included 'parentor guardian of an incompetent nominee or an assignee or who claims to be otherwise entitled to the takaful benefits under the relevant law'. ${ }^{3839}$

While the parent or guardian of an incompetent nominee is plainly clear, the new definition of proper claimant includes an assignee as well. An assignee is a person who receives the transfer of ownership initiated by the assignor under the contract of assignment. The IFSA 2013 recognises the contract of assignment as an instrument for the assignor (takaful participant) to transfer the takaful benefits to the assignee (beneficiary) upon the death of the assignor. Based on the practice in

Section 65(4) of the TA 1984 (Act 312).

Section 2 of the IFSA 2013 (Act 759).

Para 9 Schedule 10 of the IFSA 2013 (Act 759). 
the takaful industry, the takaful participant may request to execute an absolute assignment to transfer the takaful benefits in favour of his or her intended beneficiary. Contrary to the effect of an executor, absolute assignment serves as an alternative avenue for the participant should he or she wish to give the takaful benefits to a specific recipient. Takaful benefits that have been assigned shall not form part of estate of the deceased takaful participant but belong absolutely to the determined recipient. ${ }^{40}$

Another category of proper claimant is a claimant 'who claims to be otherwise entitled to the takaful benefits under the relevant law.' This implies to another recipient of takaful benefits under the category of conditional hibah as provided under Schedule 10 of the IFSA 2013.

Takaful participants are allowed to choose their manner of payment for their takaful benefits as follows:

(a) designate a nominee to receive the benefits as an executor who will distribute such benefits in accordance with the relevant inheritance laws;

(b) designate the nominee to receive the benefits as a beneficiary under conditional hibah; or

(c) assign the benefits to an assignee under absolute assignment.

\subsection{Payment of Takaful Benefits}

The TA 1984 is silent on the details of payment of takaful benefits and takaful operators have different practices in regulating the treatment of takaful benefits. $^{41}$

Based on the previous practice, takaful operators are not required to display the options available to customers. Thus, by default, some takaful operators adopt

40 Para 7 Schedule 10 of the IFSA 2013 (Act 759).

41 Takaful Act 1984 
the payment of takaful benefits direct to the nominee who acts as an executor who will then distribute such benefits in accordance with the relevant inheritance laws. ${ }^{42}$

On the other hand, a takaful participant who wishes to have his or her takaful benefits paid to a determined nominee as a beneficiary may execute an absolute assignment form. However, this option is available only upon request by the participants and not embedded in the application form or nomination form. ${ }^{43}$

However, with the introduction of the IFSA 2013, the manner of payment of takaful benefits has been thoroughly detailed in Schedule 10 of the IFSA 2013 as the takaful operators are now statutorily required to prominently display in the nomination form that the takaful participant may:

(a) assign the takaful benefits to a person or designate the nominee to receive such benefits as a beneficiary under conditional hibah; or

(b) designate the nominee to receive the takaful benefits as an executor.

With the introduction of the IFSA 2013, its Schedule 10 now has become a very powerful provision where it states that this schedule shall have full force and effect notwithstanding anything inconsistent with or contrary to any other written law relating to probate, administration, distribution or disposition of the estates of deceased persons, or in any practice or custom in relation to these matters.

Although Schedule 10 of the IFSA 2013 requires Takaful operators to prominently display the options of payment of takaful benefits to takaful participants in the nomination form, it is not mandatory for the participants to choose the preferred option. This is apparent from the fact that para 8 , Schedule 10 of the IFSA 2013 provides for payment of takaful benefits where there is no nomination.

42 Surianom Miskam and Muhammad Amrullah Nasrul (2014). Shariah Governance in Islamic Finance: The Effect of the Islamic Financial Services Act 2013. Selangor Kolej Universiti Islam Antarabangsa Selangor.

43 Surianom Miskam and Muhammad Amrullah Nasrul (2014). Shariah Governance in Islamic Finance: The Effect of the Islamic Financial Services Act 2013. Selangor Kolej Universiti Islam Antarabangsa Selangor. 


\subsection{Expended Power of Bank Negara Malaysia}

The role, function and power of BNM have been expanded under the IFSA 2013. ${ }^{44}$ BNM now has the power to issue directions to institutions including takaful operators. It can carry out intervention and remedial actions to avert or reduce any risk to the country's financial stability. The BNM control the business of the Takaful as the Minister may, on ecommendation of the BNM prescribe any business or activity as Takaful Business. ${ }^{45}$

\section{Conclusion}

As it can be seen from the key changes above, the new IFSA 2013 has an important reflection on takaful operators in Malaysia. These will lead to considerable changes in the industry. It will also set a new benchmark for takaful regulations in other countries.

It is also yet to be seen if the IFSA 2013 will encourage takaful operators to continue and take on more social and religious responsibilities despite the higher operating costs due to the new regulation. Will they promote the idea of social welfare of Islam more for example by providing cover for lower income groups which are currently underserved by the takaful and insurance industry in Malaysia.

\section{References}

Daljit Dhesi: The Star Online. (2013). New Rules to See Some Takaful Companies Seperating Life and General Operation. Retrieved on 18/6/2016.

Kulsanofer Syed Thajudeen. (2014). IFSA 2013: Rational, Salient Features and Possible Issues. Kuala Lumpur: The Global University in Islamic Finance.

Macel Omar Papp. (2014). Impact of the new Malaysian IFSA 2013 regulation on Takaful and Retakaful operators.

Salman Bin Lambak, Mohd Shukri Bin Jusoh and Hartini Bin Abd Ghani. (2014). Legitimacy of Adapting Common Law in Islamic Financial Services Act 2013. Terengganu: International Journal of Business and Social Science.

Shariah Resolutions in Islamic Finance, (2nd Ed), Kuala Lumpur, Bank Negara Malaysia, 2010, p 91.

44 Section 7 of the IFSA 2013 (Act 759).

45 Section 4(5)(a) of the IFSA 2013 (act 759). 
Surianom Miskam and Muhammad Amrullah Nasrul. (2014). Shariah Governance in Islamic Finance: The Effect of the Islamic Financial Services Act 2013. Selangor: Selangor Kolej Universiti Islam Antarabangsa.

Zainal Abidin Mohd Kassim and Farzana Ismail. (2014). Updates on Takaful:Regulating the Way Forward.

Islamic Financial Services Act 2013 (Act 759).

Takaful Act 1984 (Act 312).

http://www.thestar.com.my/business/business-news/2013/04/01/new-rules-to-seesome-takaful-companies-separating-life-and-general-operations/ 